\title{
TECHNOLOGIES OF SELF-CULTIVATION HOW TO IMPROVE STOIC SELF-CARE APPS ${ }^{1}$
}

\author{
MATTHEW DENNIS
}

\begin{abstract}
Self-care apps are booming. Early iterations of this technology focused on tracking health and fitness routines, but recently some developers have turned their attention to the cultivation of character, basing their conceptual resources on the Hellenistic tradition (Stoic Meditations ${ }^{\mathrm{TM}}$, Stoa ${ }^{\mathrm{TM}}$, Stoic Mental Health Tracker ${ }^{\mathrm{TM}}$ ). Those familiar with the final writings of Michel Foucault will notice an intriguing coincidence between the development of these products and his claims that the Hellenistic tradition of selfcultivation has much to offer contemporary life. In this article, I explore Foucault's cryptic remarks on this topic, and argue that today's self-care developers can improve future products by paying attention to the Hellenistic exercises of self-cultivation he identifies as especially important.
\end{abstract}

Key words: self-care; app-based technology; Foucault; Hellenistic philosophy.

\section{Introduction}

Recently moral philosophers in the analytic tradition have become increasingly concerned with the cultivation of character. Philosophers such as Harry Frankfurt to Susan Wolf build on the insights of earlier thinkers such as Iris Murdoch to Bernard Williams to argue that traditional moral philosophy does not pay enough attention to the self-directed practices through which many of us orientate our lives. Moreover, although none of these thinkers are card-carrying virtue ethicists, they all view self-directed character development to be an important component of a flourishing life. Murdoch's account of 'spiritual exercises' (1962, p. 51), and Williams' account of 'ground projects' (1976/1981, p. 13), are both important precursors to Frankfurt's notion of 'care' (1982, p. 84) and Wolf's notion of 'meaningfulness' (2015, p. 124). While the cultivation of character is a relatively new topic in analytic philosophy, continental ethicists (and the figures in the history of philosophy from which they draw) have investigated this topic for far longer. Thinkers in this tradition, notably Michel Foucault, claim that 'technologies of the self' can allow us to direct our

1 Thanks to the audience of the annual conference of the Jubilee Centre of Character and Virtue for their excellent comments and discussion at Oxford University in January 2020. 
practical lives in highly valuable ways that the mainstream philosophical tradition has ignored. In contrast to philosophers who emphasise the importance ethical concepts deriving from a root notion of human autonomy (freedom, responsibility, blame), Foucault views our freedom to direct our practical lives as fragile and malleable, unless we bolster our meagre sovereign powers with a life-long practice of self-shaping. Furthermore, as I examine in detail below, Foucault suggests that the Hellenistic tradition holds the conceptual resources to explain how to engage in self-cultivation, resources he predicts will apply to $21^{\text {st }}$ century life.

In this article, I examine how Hellenistic practices of self-shaping have recently been integrated into self-care apps (Stoic Meditations, ${ }^{2}$ Stoa, ${ }^{3}$ Stoic Mental Health Tracker ${ }^{4}$ ). To do this, I survey how today's Stoic-style self-care apps make use of online technology in a way that goes beyond anything that Foucault (or the Hellenistic philosophers) could have anticipated. Gamification, the availability of large-scale data sets, and the capacity to create virtual communities give developers new tools. These, I argue, can either turn self-care apps into profit-driven distractions, or they can be employed to promote emancipatory ethical goals. After looking at how these Stoic-style apps work, I sketch out how understanding Foucault's interpretation of Hellenistic practical philosophy allows us to think more deeply about how to direct future innovations in self-care app technology.

\section{Stoic-Style Self-Care Apps}

Given the boom in self-care apps since the early 2010s, it was perhaps inevitable that, sooner or later, developers would create ones based on the Stoic tradition. Early examples of these apps, such as The Stoic (Tamago Labs) ${ }^{5}$ or Daily Stoic Quotations (GV apps) ${ }^{6}$, simply presented the user with an easy-to-access compendium of well-known Stoic quotations. This first-wave of Stoic-style apps essentially replicate what Ryan Holiday, a well-known advocate of Stoicism, aims to do in his book, The Daily Stoic: 366 Meditations on Wisdom, Perseverance, and the Art of Living. These apps present the user with a daily dose of Stoic material to read and mediate on during their day. Diurnal reading is not only a way to present Stoicism to modern readers with short-attention spans, however. It is well-documented that the Stoics themselves regarded this way of reading the founding texts of their school as highly important. Foucault strongly emphasises this (1983a, pp. 207-22). ${ }^{7}$ As I argue in 4.3, understanding him on the Stoic practice of daily reading - what he calls hupomnemata points to an interesting way in which app developers could improve the users' incorporation of Stoic material.

\footnotetext{
Available at: https://apps.apple.com/us/app/stoic-meditations/id1123446805

Available at: https://play.google.com/store/apps/details?id=stoameditation.stoa

4 Available at: https://apps.apple.com/us/app/stoic-mental-health-tracker/id1312926037

5 Available at: https://play.google.com/store/apps/details?id=rocks.tommylee.apps.dailystoicism \&hl=en.

6 Available at: https://play.google.com/store/apps/details?id=com.gvapps.stoicism

7 See especially Foucault's posthumously titled essay, 'Self-Writing' (1997 [1983a], pp. 207-22). This text is the transcript of a seminar that took place in 1983.
} 
Moving on from first-wave Stoic-style self-care apps with basic functionalities, a second-wave of apps combined textual gobbets of Stoic texts with exercises, emphasising the Stoic idea that theory is best incorporated into the individual's character through the use of practices that the individual regularly performs. Stoic Meditations (Adam Musial-Bright), Stoa (ChangeWell apps), Stoic Mental Health Tracker (Maciej Lobodzinski) illustrate this well. Like first-wave Stoic-style apps, these apps provide daily doses of text from famous Stoics, but they also give the user to option to actively participate, motivating them to take up a virtual version of an exercise of self-cultivation that the Stoics promoted. Take, for example, Seneca's claim that the 'mind should be called to account daily', or his description of Sextius' nightly practice of asking himself 'Which of your failings have you cured today? Which vice have you resisted? In what respect are you better?' (Seneca, c. 45 CE/2004, p. 186 [36.1]). Seneca claims that doing this enables him to better reflect on which of his virtues he wants to improve. In the same way, Stoic-style apps can gamify the practice of a morning meditation or a nightly 'taking-stock' exercises in a way that aims to update the original Stoic practice.

Stoa and Stoic Meditations both include a podcast on Stoic practices by Massimo Pigliucci, a popular neo-Stoic commentator, as well as hosting curated quotations and (all of) Seneca's extant letters. In addition to this, Stoic Meditations pairs up these texts (albeit loosely, as I explore below) with a Stoic exercise that the user is encouraged to perform. For example, the app connects Seneca's Letter 4, 'On Groundless Fears', with a night-time reflective exercise. In Letter 4, Seneca notes that: 'There are more things likely to frighten us than there are to crush us; we suffer more often in imagination than in reality.' This thought is paired - somewhat incongruously, perhaps - with the exercise to: 'Write down one thing you want to improve next day, no matter how small. You may be surprised how much you change if you keep this up for months on end' (Stoic Meditations 2019).

Stoic Mental Health Tracker adopts a similar approach. This app offers a greater range of Stoic exercises, ranging from negative visualisation to journaling about one's day, from meditation to breathing exercises (I return to the former two in the first two parts of section on 'Technologies of Self-Cultivation'). Most significantly, however, it uses advanced technological abilities to gamify the users experience, taking the practice of Stoicism into the $21^{\text {st }}$ century. Users can see how many times they have done a specific meditation, for instance, and can opt to be notified when they stop using the app on a daily basis. In addition to this, users can (1) see their history of behaviour on the app, (2) its integrated 'HealthKit' directs them towards trends in their practice, and (3) graphics highlight which exercises they typically find most useful and important. These functionalities give the app a practical value that surpasses traditional teaching and media. It provides a more personalised and integrated experience that combines the advantages of first-wave apps like Stoa and Stoic Meditations (discussed above) with $21^{\text {st }}$ century app-based technology.

Nevertheless, the current state of Stoic-style apps seems to deviate from core Stoic teachings in important ways. Despite Stoic Meditations listing Massimo Pigliucci as its 'academic advisor', we saw above that its pairing of Seneca's Letter 4 with the injunction to write down lists of 'daily improvements' does not clearly connect with the content of the letter. In a similarly unorthodox way, Stoic Mental Health Tracker (not endorsed by Pigliucci) mixes quotations from 'stoic philosophers' (sic) with those from 'Lao Tzu, 
The Holy Bible, and Gautama Buddha' (Stoic Mental Health Tracker 2019). While this approach may strike some as eclectic and ecumenical, it may well strike others as muddying a venerable philosophical tradition with source material to which it is only superficially related. Furthermore, it would be difficult to describe the ethical ideal that these apps direct the user toward as decisively Stoic. Instead of encouraging users to resist the impulses of their emotions, these apps are much more concerned with guiding them towards a more generic state of 'well-being', one which William Irving, a contemporary Stoic scholar, describes as 'spending one's days seeking an interesting mix of affluence, social status, and pleasure' $(2009$, p. 6). So can such apps redirect their energies in order to create a product that is more in keeping with Stoic ideals? And, if this is possible, how can they practically do this? We can find tentative answers to both these questions, I contend, by examining Foucault's texts on the Hellenistic tradition, most of which were only released after his death in 1984.

\section{The promise of Hellenistic self-cultivation for the $21^{\text {st }}$ Century}

Foucault's posthumously published interviews and seminar transcripts make a remarkable set of claims regarding the importance of what he terms 'technologies of the self' (1982b, p. 223). These comments have typically confounded Foucault scholars, as there is clear mismatch between the Hellenistic world from which he draws his examples, and the late twentieth-century context to which he seeks to apply them. I argue that re-reading his wellknown passages on Hellenistic self-cultivation in the light of recent developments in selfcare app technology goes some way to reconstructing the direction of Foucault's thought in his final texts, however. It also helps to shed light on the historical context in which today's self-care app technologies have arisen - and, arguably, how Foucault's historically nuanced account of this context could inform future iterations of these technologies in ethically progressive ways.

In his posthumously titled seminar transcript, 'About the Beginning of the Hermeneutics of the Self', Foucault initially claims that the contemporary subject has no 'positive foundation' because it is simply the 'historical correlation of technology built into our history' (1980, p. 222). On the second day of the seminar, however, he qualifies this thought, countenancing the idea that we can 'change those technologies' in a process he calls the 'politics of ourselves' (1980, pp. 222-3). ${ }^{8}$ Expanding on this thought in 1983, Foucault writes that the Hellenists harbour a 'treasury of devices, techniques, ideas, procedures that, [although] cannot exactly be reactivated, at least constitute [...] a certain point of view which can be very useful as a tool for analysing what's going on now - and to change it' (1983b, p. 261). The ambiguity of these claims has ensured that they continue to create fierce debate amongst Foucault scholars (Elden, 2016; McGushin, 2007; O'Leary, 2002).

\footnotetext{
8 Martha Nussbaum and Pierre Hadot are critical about Foucault's emphasis on the importance of the Hellenistic exercises of self-cultivation. As well as disagreeing with what they regard as the overlydiminutive role that Foucault gives to philosophy in his account of the pratiques de soi, both these thinkers claim that his focus on self-cultivation is in direct tension with his earlier philosophical legacy, and warn us to be sceptical of it.
} 
Prima facie there is a paradox in this change of emphasis, which Martha Nussbaum focuses on in her scathing review of the English translation of The Use of Pleasure (1984a). Here she tells us that Foucault's interest in self-cultivation in this work is a 'retreat from the principles that defined his career' (1985, p. 13). Expanding on this view in The Therapy of Desire, she claims that 'it is questionable whether Foucault can even admit the possibility of such a community of freedom, given his view that knowledge and argument are themselves tools of power' (1994, pp. 5-6; cf. p. 353). Nevertheless, a more plausible - not to mention, more charitable - reading of Foucault's position is to view his later work as simply the extension of the themes he had explored earlier. We could say that the technologies of power (of his early work) are deeply constitutive of the subject, but the technologies of the self (of his later work) allow the subject to choose to constitute itself in a way that can allow it to actively resist technologies of power. If we agree with Foucault's claim that Hellenistic philosophy offers a 'treasury of devices, techniques, ideas, procedures' for contemporary self-cultivation, then the current development of self-care app technology could provide a case study of how we can 'change those technologies' in ethically or even politically progressive ways. So how might Foucault's detailed account of Hellenistic self-cultivation provide the conceptual resources to reinvigiorate Stoic-style self-care apps? Could his account of these technologies improve them in any significant way?

\section{Technologies of self-cultivation for the $21^{\text {st }}$ Century}

This section shows how Foucault's work could improve upon exiting self-care technology. First, I outline three key technologies of Hellenistic self-cultivation that Foucault identifies as especially important. Second, I explore the extent that existing Stoic-style apps, which I examined in in the section on 'Stoic-style Self-Care Apps', are doing similar things. Third, I highlight those aspects of Foucault's listed technologies that are not covered by Stoic-style apps, ones which perhaps offer propitious possibilities for future development.

\section{'Controlling our representations'}

Many of us are worried about pernicious effect of content we consume online. Given that the Stoics lived in a milieu in which the over consumption of print or image was not identified as a problem, their exercise of 'controlling one's representations' was not primarily aimed at reducing distraction from images outside the self. Rather, it aimed to combat one's own mental images, either of future fantasies or of regretful memories. For the Stoics, excessive functioning of either the memory or the imagination presented a threat to the flourishing life, which the Stoics view as freedom from emotion (apatheia). The exercise of controlling our representations consists, Foucault tells us, in an 'attitude of constant supervision over the representations that may enter the mind' (1982a, pp. 103-4). Foucault gives two accounts of how such vigilance can best constitute a remedy for excessive or unwanted representations. Epictetus, he writes, explains the practice using two metaphors:

[First,] that of the night watchman who does not let just anyone come into the town or the house; and [second] that of the moneychanger or inspector-the arguronomos - who, when 
presented with a coin, examines it, weighs it in his hand, and checks the metal and the effigy.

(1982a, pp. 103-4)

Watching 'perpetually over representations' was often combined with an 'evening examination', such as I explored in my above discussion of the Stoic-style app, Stoic Routines. Like the interface of the app, in a morning examination, one considers how one has performed the 'tasks and obligations of the day', alongside examining one's conscience at night to 'review the day that had gone by' (1982b, p. 240; 1984b, pp. 60-1). To do this, the participant sifts each memory-image of the day, evaluating it according to whether it fits with the ideal of apatheia to which they strive to attain. Similarly, when conducting a morning examination, the participant evaluates the imaginative predictions of the day ahead, assembling them into a reflective hierarchy of desirability.

In a similar vein, Stoic Mental Health Tracker, offers both a morning and evening meditation, glossed as a 'prepare for the day with a morning routine' meditation, and a 'reflect on your actions during the evening' one (Stoic Mental Health Tracker 2019). The app combines this with a journaling function, one that allows the user to keep a written record of the epiphanies that their meditations have precipitated. Nevertheless, given how the consumption of excessive or unsavoury content is a source of concern for many of us, we have reason to think that Stoic-style apps could pay greater attention to this. According to the original Stoic practice, images and representations have much power to define our mental lives. This insight might lead us to support the idea that Stoic-style self-care apps could adopt more sophisticated and intensive controls for our consumption of online content. Indeed, they could do better with respect to the controlling of representations if they included a functionality that would monitor the user's consumption of online content, even when they were not logged in to the app itself.

\section{'Praemeditatio Malorum' and 'Meletē Thanatou'}

Foucault tells us that in the Hellenistic world the practices of praemeditatio malorum and the melete thanatou were ways to 'judge each action one is performing in terms of its value' (1982a, p. 105). Both these exercises were concerned with changing the conditions of our evaluative perception, so that we could see a particular aspect of our life with greater clarity, one that sets this aspect in the context of our life as a whole. The aim of the praemeditatio malorum, Foucault explains, was not to 'visualise the future as it is likely to be', but rather to 'systematically imagin[e] the worst that might happen', even if this was not likely to happen at all. The aim of the melete thanatou was both to prepare for death, as well as encouraging the initiate to 'live each day as if it were the last' (1982a, p. 103). While both exercises may sound pessimistic, even needlessly morbid, Foucault emphasises that they aimed to evaluate one's worldly attachments, or as he puts it allowing one to 'judge each action that one is performing in terms of its own value' (1982a, p. 105). Visualising the events imagined in the praemeditatio malorum or melete thanatou did not aim to prepare the practitioner for the future occurrence of these events, but rather to precipitate insights into whether the practitioner was living well or badly. Although these exercises have a different focus, there are benefits both exercises could be said to share. The praemeditatio malorum primarily 
aimed to bolster positive emotions, encouraging the participant to value and reappreciate the life that they had become accustomed to enjoying. The melete thanatou shares this dimension in even starker form, insofar as death is regarded as a greater evil than illness. Foucault cites Seneca urging Lucilius to live 'each day as if one's entire life depended on it' (1982a, p. 105). Similarly, we could think of the Roman statesman's account of this in 'On the Shortness of Life', where Seneca gives an extended account how meditating on our finitude helps us live more fully (2007/55-65 CE, pp. 140-162).

There have been attempts to incorporate both these meditations into Stoic-style apps. The meditation on death is, of course, a prominent feature in the Stoic literature, and those apps that include texts by Stoics such as Seneca or Epictetus invariably include reference to it. This does not make use of the technology that powers the app itself, of course, and is analogous to the variations of this exercise have been proposed by other traditions that deal with self-directed character change. For example, the celebrated self-help theorist Stephen Covey proposes that a version of this exercise can get our prudential considerations into focus (1989, p. 45). As well as this, however, praemeditatio malorum and the melete thanatou have both been coded into apps to give the user a more direct experience of the practice, analogous to how it would be to undergo the mediation with a trained Stoic teacher or sage. Stoa, for example, offers versions of both meditations. Users are told that 'after completing the[ir] introductory meditation course', they can begin 'advanced Stoic meditations', including the 'praemeditatio malorum and meditations on death' (Stoa 2019). Nevertheless, in their current forms, these exercises only proceed by enjoining the user to think about death, without making much use of the power of the technologies by which they are supported.

One way in which we might be able to see how self-care apps do this is by looking at other apps that offer a similar function, albeit inspired from other traditions. An example of this is WeCroak, created by Brooklyn-based developer Hansa Bergwall. This app sends users five randomly timed reminders of their mortality, in the form of poetry or religious texts that deals with this theme. Instead of using the resources of the Hellenistic tradition, however, the founders of this app tell us that the idea for it came from the folk Bhutanese saying that one should contemplate death five times a day to find true happiness. The effect of being prodded with notifications in the midst of our daily activities in order to revaluate what we are doing in the context of the fact that we will not be able to continue to do it indefinitely, introduces a different dimension to the exercise that the vague instruction to 'contemplate death' would not have the power to do. The notification technology that WeCroak employs has the effect of increasing the user's awareness of their mortality at all times, even when they are not logged on to the app.

\section{'Hupomnemata'}

Hupomnemata, the Greek term for notebooks devoted to reflections on one's character and self-development, were popular in the Hellenistic world. Foucault emphasises that the practice of writing hupomnemata was not simply to record or represent the life of the practitioner. He tells us that they comprised collections of notes and fragments that acted as a highly personalised practical guide for an ongoing process of self-development. 
Hupomnemata were assembled diachronically (usually over months or years). They catalogued whatever the practitioner regarded as pertinent to their way of life. It was not only personal observations, however. These notebooks comprised highly personalised endoxa $-\mathrm{a}$ bricolage of the 'already said', as Foucault puts it - for the purpose of 'shaping the self' (1983a, p. 211). In summary, practice of hupomnemata consisted in two parts. On the one hand, it functioned as a repository of practical texts that aimed to intensify and deepen the practitioner's self-directed character development. On the other, it served as a reflective forum to analyse and evaluate the insights generated from other exercises of self-cultivation.

Foucault's account of hupomnemata distinguishes the practice from 'journaling', which as well as featuring widely in the self-care community, is incorporated into some Stoic-style self-care apps. Both Stoa and Stoic Mental Health Tracker include a journaling function, although in both these apps it essentially takes the form of basic notetaking. Of course, a fortiori, the positive psychology literature that supports the efficacy of journaling in general, also supports the incorporation of this function in a self-care app (Khramtsova \& Glasscock 2010). Nevertheless, if we attend to the nuances of Foucault's appraisal of hupomnemata, then there is reason to think that the Stoic-style self-care apps could be improved if they made full use of the online functionalities that, for instance, enable users to append personalised notes to the hosted Stoic texts, for instance. Stoic Mental Health Tracker prompts users to engage in specific meditations with an in-text reminder, but the ability to add a note that records one's own responses to the text (and allows one to search these responses according to theme, say) would be even more useful. Developing functionalities that relate to the searching of key words would be a modern way to develop the Stoic emphasis on finding common notions between one's thoughts, for instance (Seneca, 2007/c.65 CE, p. 49). This would enable users to search for key terms that appear in the Stoic literature, while linking them to the very terms with which they have documented their own meditation practice.

\section{Conclusion}

Understanding the reasons for Foucault's late interest in the self-shaping practices of the Hellenistic world, and his final comments on the importance of technology, offers a philosophical contribution - and perhaps a useful antidote - to today's commercial selfcare world. Furthermore, it relates the conceptual resources of Stoicism to contemporary self-care apps. Foucault's account of Hellenistic practices of self-cultivation is highly nuanced. He introduces layers of complexity that today's self-care apps do not include. This gives his analyses much potential to benefit these products. By understanding the nuances of hupomnemata or praemeditatio malorum, say, we can understand how self-care apps could deepen their incorporation of these practices, as well as seeing one way to interpret Foucault's cryptic claim that the ancient technologies of self-cultivation have practical application in contemporary life. I have shown that existing Stoic-style self-care apps do this to some extent. Nevertheless, I have argued that even what I have called 'second-wave' apps could be improved if they were designed with recourse to interpreters of Hellenism with as much erudition as Foucault. Moreover, there are reasons why the Hellenistic technologies of the self are well-suited to being hosted on a online platform such as an app, especially when 
this application is situated on a portable mobile device. The devices that apps are designed for are small enough to carry and highly personalisable, which makes them, potentially, an efficacious tool for self-cultivation. In addition to this, thinking about these technologies in the context of Foucault's cryptic comments on 'technologies of the self' and the 'politics of ourselves', offers a way in which scholars of his work can understand his remarks on this topic. At most, Foucault could only have had a hazy intimation about the technologies of the self that advances in late $20^{\text {th }}$ and now early $21^{\text {st }}$ century computer science would bring. The technological explosion that we have witnessed since his death has been unprecedented, so although he may have been right that the Hellenistic tradition has a unique role to play in the development of technologies of self-cultivation in our own era, he clearly could not have envisaged the details of this role to any significant degree. Nevertheless, even without clearly predicting how precisely these technologies of self would develop in the future, Foucault's account of Hellenistic exercises of self-cultivation still offer resources that can be employed in the development of emergent self-care technologies. Even the second-wave of Stoic-style self-care apps are lacking in important respects, so a greater integration of the philosophical tradition in this area has much potential to yield valuable insights on how to improve this kind of technology.

\section{References}

Elden, S. (2016). Foucault's last decade. Cambridge: Polity Books.

Foucault, M. (1980/1993). About the beginning of the hermeneutics of the self: Two lectures at Dartmouth. Political Theory, 21(2), 198-227.

Foucault, M. (1982a/1997). The hermeneutic of the subject. In P. Rabinow (Ed.), R. Hurley (Trans.). Ethics: Subjectivity and truth (pp. 93-108). London: Penguin Books.

Foucault, M. (1982b/1997). Technologies of the self. In P. Rabinow (Ed.), R. Hurley (Trans.), Ethics: Subjectivity and truth (pp. 223-251). London: Penguin Books.

Foucault, M. (1983a/1997). Self-writing. In P. Rabinow (Ed.), R. Hurley (Trans.). Ethics: Subjectivity and truth (pp. 207-22). London: Penguin Books.

Foucault, M. (1983b/1997). On the genealogy of ethics: An overview of work in progress. In P. Rabinow (Ed.), R. Hurley (Trans.). Ethics: Subjectivity and truth (pp. 253-80). London: Penguin Books.

Foucault, M. (1984a/1985). History of sexuality II: The use of pleasure. (R. Hurley, Trans.). London: Penguin Books.

Foucault, M. (1984b/1986). History of sexuality III: The care of the self. (R. Hurley, Trans.). London: Penguin Books.

Frankfurt, H. (1982/1998). The importance of what we care about. In The importance of what we care about (pp. 80-94). Cambridge: Cambridge University Press.

Frankfurt, H. (2004). The reasons of love. New Jersey: Princeton University Press.

Hadot, P. (1987/1995). Philosophy as a way of life: Spiritual exercises from Socrates to Foucault. (M. Chase, Trans.). Oxford: Blackwell Publishing.

Khramtsova, I., \& P. Glasscock. (2010). Outcomes of an integrated journaling and mindfulness program on a US university campus. Revista de psihologie,56(3), 208-17.

Klincewicz, M. (2019). Robotic nudges for moral improvement through stoic practice. Techné: Research in Philosophy and Technology, 23, 3, 425-455. doi: 10.5840/techne2019122109)

McGushin, E. (2007). Foucault's askesis: An introduction to the philosophical life. Northwestern University Press. 
Murdoch, I. (1962/2001). On 'God' and 'Good'. In The sovereignty of good (pp. 45-74. New York: Routledge.

Nussbaum, M. (1985, November 10). Affections of the Greeks. Review of The use of pleasure. New York Times Book Review, 3-14.

Nussbaum, M. (1994/2009). The therapy of desire: Theory and practice in hellenistic ethics. New Jersey: Princeton University Press.

O'Leary, T. (2002). Foucault and the art of ethics. London: Bloomsbury Publishing.

Seneca (2008). De Ira. In B. Inwood and L.P. Gerson (Eds.), The stoics reader. Indianapolis: Hackett. (Original work published ca. $45 \mathrm{CE}$ )

Seneca (2004). Letters from a stoic. (R. Campbell, Ed. \& Trans.). London: Penguin Books. (Original work published ca. $45 \mathrm{CE}$ )

Seneca (2007). Dialogues and essays. (J. Davie, Trans.). Oxford: Oxford University Press. (Original work published ca. 55-65 CE)

Williams, B. (1985). Ethics and the limits of philosophy. Cambridge, MA: Harvard University Press.

Wolf, S. (2002). Meaning in life and why it matters. New Jersey: Princeton University Press.

Department of Values, Technology, and Innovation

Office B3.330

Jaffalaan 5

2628 BX Delft

The Netherlands

Email: M.J.Dennis@tudelft.nl 